International Journal of Modern Anthropolagy

Int. J. Mod. Anthrop. 2021. Vol. 2, Issue 15, pp: 469 - 482

DOI: http://dx.doi.org/10.4314/ijma.v2i15.4

Available online at: www.ata.org.tn \& https://www.ajol.info/index.php/ijma

Research Report

\title{
Misinformation about COVID-19 among internet users in Nigeria: Tools to effective public awareness, prevention and control.
}

\author{
Kayode Adeyemi \\ Clinical Trial and Training Center, ISTH. Edo State, Nigeria.Email adeyemikayode399@gmail.com
}

(Received 14 April 2021; Accepted 05 May 2021; Published 20 May 2021)

\begin{abstract}
Since the World Health Organization announced in early 2020 that the COVID-19 pandemic was accompanied by an infodemic of misinformation, we are left with the question of public perspective-driven compliance to safety measures. This preliminary study evaluated some claims about COVID-19 including vaccine conspiracy theories among Nigerians with factors influencing it. An online structured questionnaire was designed to collect one-time data from voluntary participants. Demographically, major respondents were; bachelor: 284 (75.1\%), age-group between 18 and 30 years: 312 (82.5\%) and male: $207(54.8 \%)$. Those that do not know the range of infected population in the country accounted for $260(72.2 \%)$. In opinion, 57 (15.1\%) supported that SARS-COV-2 cannot survive the warm climate of African continent, and $41(10.8 \%)$ believed the hoax theory about COVID-19. Unapproved herbal medication was reported to be used by 251 (66.4\%) of the respondents while 92 (24.3\%) made use of Chloroquine. For transmission related conceptions, $52(13.8 \%)$ indicated that an asymptomatic carrier cannot spread the virus to another healthy individual. About half of the respondents $182(48.1 \%)$ suspected that SARS-COV-2 was an engineered virus and 173 (45.8\%) supported that there are underlying negative intentions on the clinical trial of COVID-19 vaccines on Africans. There is a weak correlation between the demographic data of the respondents and the claims. The level of misconception Nigerians have about COVID-19 is a major concern. Thus, it is imperative to continuously engage in community awareness and education using proven facts about the virus, and its available prophylaxis measures in order to avoid the dangers that are associated with the prevailing misconceptions.
\end{abstract}

Keywords: Misinformation, Vaccine conspiracy, COVID-19, Compliance. 


\section{Introduction}

Misinformation has been said by the BBC to have huge consequences on public health (BBC News 2021) and public perspective on contagions like the ravaging COVID-19 had also been reported to ultimately influenced the level of compliance to safety measures (Bridgman et al. 2020; Nsoesie \& Oladeji 2020). Inference can also be made from the case of Ebola outbreak in 2014 when members of the community trusted in fate to put an end to the disease and consequently recorded declined commitment, compliance and reported cases (Yusuf et al. 2014). One will think that it is well enough to curb community transmission when governments of most countries, private and public enterprises are providing basic regulatory measures such as running water with soap, or alcohol-based hand sanitizers in strategic public places (ITUC-AFRICA 2021), but compliance is still dependent on factors such as enforcement, political interference, education and various other factors related to the public (Sandada \& Kambarami 2016). Compliance itself is a transferrable psychological practice especially when the projecting personnel that breach standard is of higher social, religious, or educational status (LUMEN 2021b). As previously mentioned by Ogbonda et al. (2020) of the effectiveness and continuity of control measures to infection can only be met when the users are thereby proactive, thus, public health departments should lay emphasis on correcting or emphasizing the general perspective of the public on issue related to their health as COVID-19.

In addition to reduced compliance, other characteristics of misinformed public include; fear, stigma, racism, and threat (Smith et al. 2020) which bread paradigm, and prejudice against intended aids and support from concerned third parties. However, if the level of awareness of the public matches up with preventive measures put in place they would appreciate rather than complaining about the practices just as the case of the EBOLA endemic (Yusuf et al. 2014). One of the factors influencing misinformation is the social group, which immensely influences has impact on compliance (Lumen 2021). However, reduced occupational stress, encouragement, education and reminder play a major role in

ensuring compliance with safety measures. Evidence of significant predictors such as gender, and year of professional experience to compliance level of health workers in NorthEastern Nigeria are to be reemphasized in the case of the current pandemic (Abdulraheem et al. 2012). Socio-demographic groups have also been suggested to 
influence misinformation by certain studies (Barthel et al. 2016). These factors are important in predicting transmission of the virus through carrying over of enormous misconceptions. It has been shown also that the connection between misinformation and real-time social behavior in relation to the speed of dissemination of such misinformation are huge challenges while putting effort to curtail the spread of infectious diseases (Krishna Kumar \& Geethakumari 2014). There is therefore the need to investigate factors responsible for community transmission of COVID-19 in Nigeria since its provenance data from the National Center for Disease Control (NCDC) has been on geometric decline from $100 \%$ in February, $60 \%$ in March, $11 \%$ in April until it remains stable at $2 \%$ since May 2020 (NCDC 2021).

This preliminary study is based on survey questions has the aim to identify the major misconception about COVID-19, SARS-CoV-2, the likely correlation between misinformation and demographic information, and the widespread of vaccine conspiracy concepts in Nigeria.

\section{Methods}

Electronic internet-based survey with predefined questions was designed to collect onetime data from the eleventh of May 2020 to second day of September 2020 from each willing participants in this study after filling a consent page preceding the research question. A respondent was given only a chance to response to the form. Questionnaire was made available to internet users in Nigeria and others that could be reached in persons through link. The visibility and dissemination of the questionnaire to the e-participants were aided by common social media and professional platforms including Facebook, Twitter handle, WhatsApp, and LinkedIn. Four social media marketers were recruited to disseminate the link to willing participants, with higher response from the WhatsApp users. Participants were of age eighteen (18) years and above and those who indicated age below this were automatically excluded from partaking in the survey. The sample size is based on a significant difference of $95 \%, 5 \%$ of margin error, and a population of one hundred and thirty-four million $(134,000,000)$ internet users in Nigeria (Nigeria: number of internet users 2023 | Statista 2020). The expected sample size is, therefore, three hundred and eighty-five (385) ("Sample Size Calculator by Raosoft Inc." 2020). Participation in the 
study was not influenced by any form of incentive. Denial of consent at the beginning of participation by intending participants was designed to lead to an automatic exclusion from the survey. Descriptive and inferential data analysis was done using SPSS version 21. Correlation Analysis using Pearson Product-Moment Correlation was used to measure the significance of correlation between the assumptions and demographic data.

\section{Results and analysis}

Responses of the participants were categorized into four groups; demographic, knowledgebased, attitudes and assumptions towards prevention and cure, the suspicious claim about the virus, its vaccine and the COVID-19 pandemic as a whole.

\section{Table 1: Demographical data}

\begin{tabular}{|c|c|c|c|}
\hline Variables & Options & Frequency & Percentage $(\%)$ \\
\hline \multirow[t]{2}{*}{ Gender } & Male & 207 & 54.8 \\
\hline & Female & 171 & 45.2 \\
\hline \multirow[t]{6}{*}{ Age group } & $18-30$ & 312 & 82.5 \\
\hline & $31-40$ & 50 & 13.2 \\
\hline & $41-50$ & 8 & 2.1 \\
\hline & $51-60$ & 5 & 1.3 \\
\hline & $71-80$ & 1 & 0.3 \\
\hline & $81-90$ & 2 & 0.5 \\
\hline \multirow[t]{5}{*}{ Education level } & First Leaving Certificate & 3 & 0.8 \\
\hline & SSCE & 29 & 7.7 \\
\hline & BSC & 284 & 75.1 \\
\hline & MSC & 49 & 13.0 \\
\hline & PHD & 13 & 3.4 \\
\hline \multirow[t]{6}{*}{ Field of profession } & Student & 107 & 28.3 \\
\hline & Education & 83 & 22 \\
\hline & Business & 34 & 9 \\
\hline & Civil Servant & 36 & 9.5 \\
\hline & Unemployed & 42 & 11.1 \\
\hline & Private Sector & 76 & 20.1 \\
\hline \multirow{3}{*}{$\begin{array}{l}\text { Current job related to taking care of } \\
\text { the sick }\end{array}$} & No & 291 & 77 \\
\hline & Yes & 86 & 22.8 \\
\hline & I don't know & 1 & 0.3 \\
\hline
\end{tabular}


The descriptive analysis of the demographic data as shown in Table 1 revealed that dominant groups among the 378 respondents were bachelor's degree holders 284 (75.1\%), of age group $18-30$ years $312(82.5 \%)$ with two (2) respondents in the age group 81 - 90 years, students 107 (28.3\%), male 207 (54.8\%), and were those whose professions are not related to taking care of the sick 291 (77\%). Students and educational related professions contributed to $190(50.3 \%)$ of the respondents. While data obtained for the age group skewed towards the right and the education level was a normal distribution data set.

\section{Common misconceptions}

There is gap in the awareness of the respondent in the each of the key areas questioned. This gap ranged from $26.2 \%$ to $99.2 \%$.

Table 2: Misconception on SARS-COV-2 and COVID-19.

\begin{tabular}{|c|c|c|c|c|}
\hline Knowledge based questions & Options & Frequency & Percentage $(\%)$ & $\begin{array}{l}\text { Knowledge } \\
\text { Percentage }\end{array}$ \\
\hline \multirow{2}{*}{$\begin{array}{l}\text { Where did the current covid-19 } \\
\text { pandemic originate from? }\end{array}$} & Others & 3 & 0.8 & \multirow[t]{2}{*}{99.2} \\
\hline & Wuhan & 375 & 99.2 & \\
\hline \multirow{2}{*}{$\begin{array}{l}\text { What Part of the body does Covid-19 } \\
\text { affects most? }\end{array}$} & Others & 13 & 3.5 & \multirow[t]{2}{*}{96.6} \\
\hline & Respiratory Tract & 365 & 96.6 & \\
\hline \multirow{2}{*}{$\begin{array}{l}\text { Is SARS-COV-2 related to MERS- } \\
\text { CoV and SARS-CoV? }\end{array}$} & Others & 130 & 34.4 & \multirow[t]{2}{*}{65.5} \\
\hline & Yes & 248 & 65.6 & \\
\hline \multirow[t]{2}{*}{ Covid-19 only affect elderly persons } & No & 358 & 94.7 & \multirow[t]{2}{*}{94.7} \\
\hline & Others & 20 & 5.3 & \\
\hline \multirow[t]{2}{*}{ Covid-19 does not affect Africans } & No & 369 & 97.6 & \multirow[t]{2}{*}{97.6} \\
\hline & Yes & 9 & 2.4 & \\
\hline \multirow{2}{*}{$\begin{array}{l}\text { Covid-19 is a conspiracy/Hoax theory. } \\
\text { It does not exist }\end{array}$} & No & 337 & 89.2 & \multirow[t]{2}{*}{89.2} \\
\hline & Others & 41 & 10.9 & \\
\hline \multirow[t]{2}{*}{ Covid-19 is a disease of the rich } & No & 362 & 95.8 & \multirow[t]{2}{*}{95.8} \\
\hline & Yes & 13 & 3.4 & \\
\hline \multirow{2}{*}{$\begin{array}{l}\text { Covid-19 virus cannot survive the } \\
\text { warm climate in African countries }\end{array}$} & No & 321 & 84.9 & \multirow[t]{2}{*}{84.9} \\
\hline & Yes & 57 & 15.1 & \\
\hline \multirow{2}{*}{$\begin{array}{l}\text { What is the average fatality rate of } \\
\text { Covid- } 19 \text { worldwide? }\end{array}$} & $1-8 \%$ & 99 & 26.2 & \multirow[t]{2}{*}{26.2} \\
\hline & Others & 279 & 73.9 & \\
\hline \multirow{2}{*}{$\begin{array}{l}\text { How many people had been affected } \\
\text { worldwide as at August } 2020 ?\end{array}$} & Others & 260 & 68.0 & \multirow[t]{2}{*}{27.8} \\
\hline & Correct Value & 105 & 27.8 & \\
\hline \multirow{2}{*}{$\begin{array}{l}\text { Which of these is the major symptoms } \\
\text { of Covid-19? }\end{array}$} & Others & 112 & 29.6 & \multirow[t]{2}{*}{70.4} \\
\hline & $\begin{array}{l}\text { Difficulty } \\
\text { breathing }\end{array}$ & 266 & 70.4 & \\
\hline \multicolumn{4}{|c|}{ Average Knowledge and Awareness Percentage } & $77.1 \%$ \\
\hline
\end{tabular}


As shown in Table 2 above, the knowledge of the respondents on SARS-COV-2 and COVID-19 was $99.2 \%$ concerning its origin, $96.6 \%$ on anatomical target in host age during infection, $94.7 \%$ on influence of geographical distribution on transmission of the virus, and $95.8 \%$ on the influence of economic status influencing susceptibility to COVID19; whereas knowledge about the degree of fatality of the virus was misrepresented by the respondents with accurate response of $26.2 \%$. Only $27.8 \%$ of the respondents knew the actual range of the infected population in the world. Of the respondents, 57 (15.1\%) indicated that SARS-COV-2 cannot survive the warm climate in African continent, and 41 (10.8\%) assumed that COVID-19 does not exist. About $70.4 \%$ rightly indicated the major symptoms of COVID-19.

\section{Prevention and Cure of COVID-19}

As shown in figure 1 below, about one-third (30.8\%) of the respondents reported that effective drug had been developed and approved to combat COVID-19, while most (66.4\%) indicated their choice to use unapproved herbal medication that is advocated to cure the disease. A perception of sole spiritual remedy to COVID-19 was reported among $16.1 \%$ of the respondents, and $24.3 \%$ indicated that anyone of Chloroquine, Goya oil, or antibiotics will cure COVID-19. Gaggling or steaming herbal concoction was reported among $15.6 \%$ to be effective to cure the disease at once. Spraying of alcohol all over the body was also indicated as effective remedy for COVID-19 by $16 \%$ of the respondents while $13.8 \%$ indicated that asymptomatic carrier cannot spread the virus to other healthy person. However, it was mostly accepted by the majority of the respondents that hand washing $(96.3 \%)$, and use of alcohol based hand sanitizer (97.1\%) are effective ways of preventing Covid-19. 


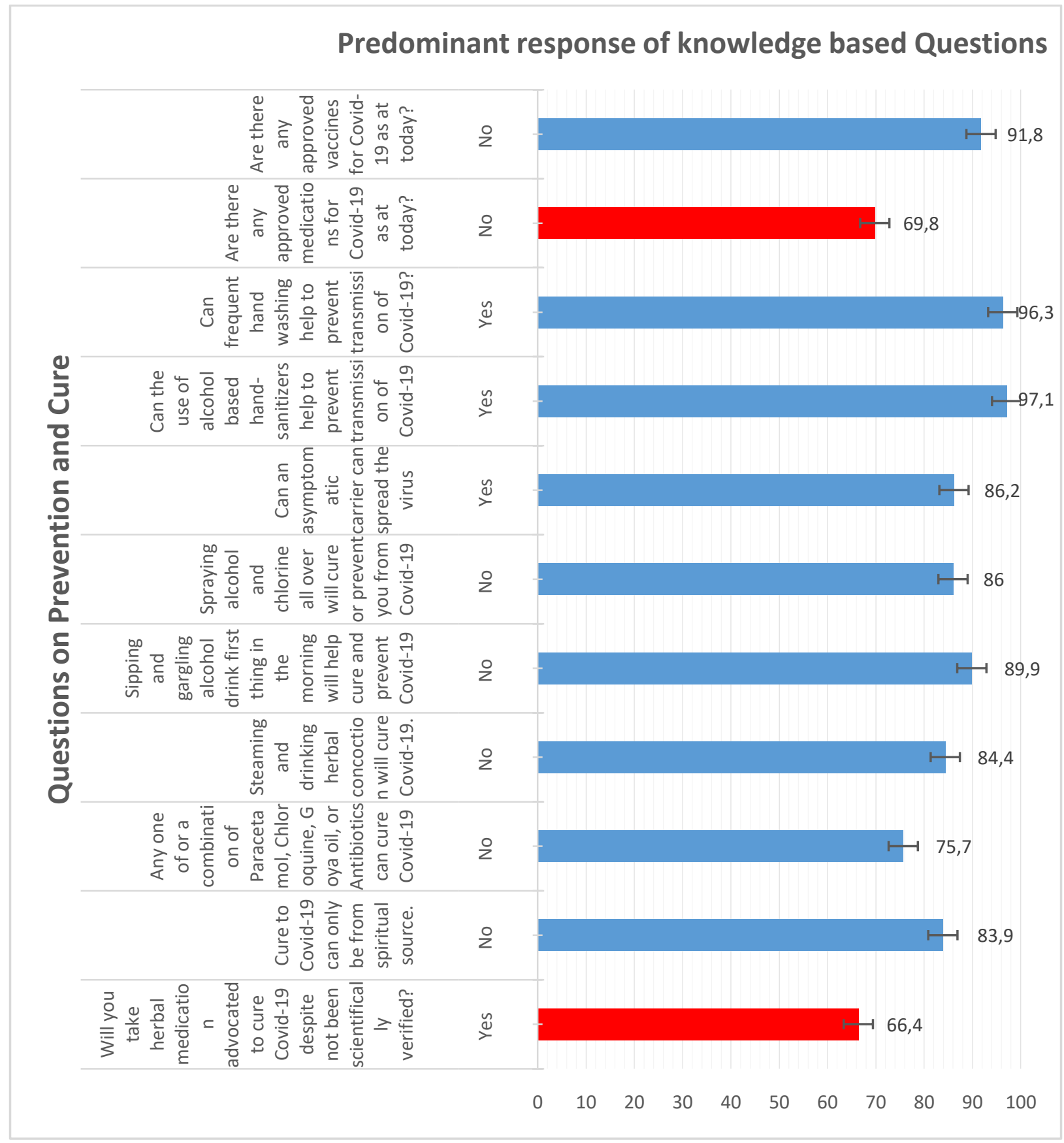

Fig. 1: Predominant Responses on Prevention and Cure of COVID-19.

\section{Suspicious Claims on COVID-19}

These are suspicions that are believed to be true concerning COVID-19 pandemic by the respondents. About $21.7 \%$ of the responded that vaccination against COVID-19 accompanied implantation of microchips into individual that takes it. While 73 (19.3\%) 
claimed that the virus was initially infused in the masks and other protective equipment donated to African countries. About half of the respondents 182 (48.1\%) claimed that SARS-COV-2 is an engineered virus developed by some world powers with the intention to depopulate the world. Very few $50(13.2 \%)$ suspected that the first global lock-down in year 2020 was indirectly enforced to give room for installation of the proposed 5G network. Also, about half $173(45.8 \%)$ of the respondents suspected that there are underlying negative intentions on the clinical trial of drugs and vaccines for COVID-19 in African continent.

Table 3: Suspicious Claims on Covid-19 in Nigeria

\begin{tabular}{|c|c|c|c|}
\hline Claims & Item & Frequency & Percentage $(\%)$ \\
\hline \multirow{4}{*}{$\begin{array}{l}\text { The use of newly developed Covid-19 } \\
\text { vaccines will accompany implantation } \\
\text { of microchips. }\end{array}$} & No & 261 & 69 \\
\hline & Yes & 82 & 21.7 \\
\hline & I don't know & 35 & 9.3 \\
\hline & Total & 378 & 100 \\
\hline \multirow{4}{*}{$\begin{array}{l}\text { Mask and protective equipment } \\
\text { donated to African countries are pre- } \\
\text { infected with Covid-19 virus from } \\
\text { China }\end{array}$} & No & 257 & 68 \\
\hline & Yes & 73 & 19.3 \\
\hline & I don't know & 48 & 12.7 \\
\hline & Total & 378 & 100 \\
\hline \multirow{3}{*}{$\begin{array}{l}\text { Covid-19 is a disease caused by an } \\
\text { 'engineered virus' by a group of world } \\
\text { power in order to depopulate the } \\
\text { world. }\end{array}$} & No & 196 & 51.9 \\
\hline & Yes & 182 & 48.1 \\
\hline & Total & 378 & 100 \\
\hline \multirow{4}{*}{$\begin{array}{l}\text { The global lock-down was enforced to } \\
\text { enable the installation of the } 5 \mathrm{G} \\
\text { network worldwide }\end{array}$} & No & 305 & 80.7 \\
\hline & Yes & 50 & 13.2 \\
\hline & I don't know & 23 & 6.1 \\
\hline & Total & 378 & 100 \\
\hline \multirow{4}{*}{$\begin{array}{l}\text { There are underlying negative } \\
\text { intentions on the clinical trial of drugs } \\
\text { and vaccines for Covid-19 in African } \\
\text { continents? }\end{array}$} & No & 171 & 45.2 \\
\hline & Yes & 173 & 45.8 \\
\hline & I don't know & 34 & 9.0 \\
\hline & Total & 378 & 100 \\
\hline \multirow{3}{*}{$\begin{array}{l}\text { Do you think that there are close } \\
\text { connections between Covid- } 19 \text { and the } \\
\text { 5G network advocated? }\end{array}$} & No & 313 & 82.8 \\
\hline & Yes & 65 & 17.2 \\
\hline & Total & 378 & 100 \\
\hline \multirow{3}{*}{$\begin{array}{l}\text { Can you allow Scientists to prioritize } \\
\text { the administration of Covid-19 vaccine } \\
\text { for the elderly and children instead for } \\
\text { the young adults? }\end{array}$} & No & 174 & 46 \\
\hline & Yes & 158 & 41.8 \\
\hline & Total & 378 & 100 \\
\hline \multirow{3}{*}{$\begin{array}{l}\text { Do you believe that some countries } \\
\text { have the cure for the Covid-19, but } \\
\text { wait till is it widespread for higher } \\
\text { monetary gain? }\end{array}$} & No & 247 & 65.3 \\
\hline & Yes & 131 & 34.7 \\
\hline & Total & 378 & 100 \\
\hline
\end{tabular}


With the awareness of available prophylaxis against COVID-19, 158 (41.8\%) of the respondents indicated that they will not prioritize the administration of COVID-19 vaccine for the elderly and children instead for the young adults. Also, about one-third 131 $(34.7 \%)$ indicated that some countries have the cure to COVID-19, but wait till is it widespread before they reveal it for higher monetary gain.

Table 4: Correlation Analysis between misconception and demographic data.

\begin{tabular}{|l|l|l|}
\hline \multicolumn{2}{|c|}{ Demographic data and misconception correlation } \\
\hline \multirow{4}{*}{ Age group } & Pearson Correlation & .032 \\
\cline { 2 - 3 } & Sig. (2-tailed) & .537 \\
\cline { 2 - 3 } & $\mathrm{N}$ & 378 \\
\hline \multirow{3}{*}{ Education level } & Pearson Correlation & .041 \\
\cline { 2 - 3 } & Sig. (2-tailed) & .427 \\
\cline { 2 - 3 } & $\mathrm{N}$ & 378 \\
\hline \multirow{3}{*}{ Field of Profession } & Pearson Correlation & .060 \\
\hline & Sig. (2-tailed) & .245 \\
\hline & $\mathrm{N}$ & 378 \\
\hline$* *$ Correlation is significant at the 0.01 level (2-tailed). & \\
\hline$*$ Correlation is significant at the 0.05 level (2-tailed). \\
\hline
\end{tabular}

The Pearson correlation coefficient of the demographic data and misinformation obtained in Table 4 above are all greater than zero (0) and positive for the age (0.032), educational level (0.041), and field of profession of the participants (0.060). Therefore a weak association exists between the misconceptions and the demographic data of the participants.

\section{Discussion and Conclusion}

Just as serology is important to evaluate the degree of herds immunity that had been achieved by a community over some period of time, it is important to assess the knowledge, and assumptions of the public on COVID-19. This is important because of the connection between the knowledge of the public and their compliance. From this study, the general knowledge index of the respondents was 0.771 out of $1.0(77.1 \%)$. There are traces of 
misinformation about SARS-COV-2 as reflected in the deviation from a perfect scale in each of the knowledge-based questions in this study. This minor knowledge gap of $22.9 \%$ has the tendency of spreading with low awareness of the public and high proximity of the recipients from sources of accurate information to verify claims; the spread of these misconceptions will be faster than the virus. There is an indication of abuse of herbal substances during the COVID-19 pandemic. Which showed a huge influence of traditional medical interventions on the decision of more than average Nigerian $(66.4 \%)$ pertaining the health. The consequence of this will be a proliferated unrefined production, consumption, and recommendation of unverified organic compounds which may have detrimental long term health implications on the consumer and public health in general. In support to the finding in this study, Ahmed et al. 2020, reported that $34.5 \%$ of respondents did not know the actual cause of the diseases, and were unable to differentiate the previous MERS-COV, SARS-COV-1 and the SARS-COV-2 (Ahmed et al. 2020). It is important therefore for public health advocates to make use of both traditional and social media to promote accurate information about the diseases, and need for vaccination (Carlson et al. 2020). Less to forget that campaign strategies will only be successful to acceptable degree when they are buffered by community education and direct support programs. It is found that a weak correlation exists between misinformation about COVID-19 and demographic data, thus, misinformation is likely to be common among some group of people than the others. Most of the youth also regards equality in access to health intervention as an important factor to be considered during the COVID-19 pandemic with $44 \%$ of the respondent showing refusal to prioritize the administration of COVID-19 vaccine to immunecompromised members of the community such as pregnant women and the elderly. Members of the community have to be educated about the mechanism which the vaccine works in their body, their safety, and the importance of the vaccine in a way that they will understand, thus, researchers and scientist should not only depend on reviewed publications to communicate their findings, or intervention in medical situations to the general public. Other avenues should be explored to communicate to the public, while scientific publication should remain educationally relevant amidst like-minded and objective scientific colleagues around the globe. Such alternative, awareness (Saunder \& Chris 2002) based avenues should be accessible to the public with the use of language and tone that is 
directed to the understanding of the general public, with protected integrity, open to discussion, feedback and questions on particular health situation at hand. One of the reasons the degree of misinformation is trajectory in both resource limited, and affluence communities are low reading habit, lack of understanding of available research articles, use of difficult terms in communication from scientist, negative influence from high social class personalities in the community, political advantages, and frustration. For tracking viral information on the social media, it is important to link every information to their source, while acceptability of such information should depend on the integrity of the speaker, and the general public should endeavour to gain full understanding of what the information denotes before circulating.

Conflict of interest: The author declares no conflict of interest

\section{References}

Abdulraheem I.S., Amodu M.O., Saka M.J., Bolarinwa O.A., Uthman M.M.B. 2012. Knowledge Awareness and Compliance with Standard Precautions among Health Workers in North Eastearn Nigeria. J Community Med Health Edu 2:131.

DOI: $10.4172 / \mathrm{jcmhe} .1000131$

Ahmed N., Rizvi A., Naeem A., Saleem W., Ahmed A., Parveen S., Ilgas M. 2020. COVID-19 and public awareness. The Professional Medical Journal. 27(08): 1710-1716. DOI: $10.29309 /$ tpnj/2020.27.08.4655

Barthel M., Mitchell A., Holcomb J. 2016. Many Americans believe fake news is sowing confusion. Pew Research Center.

https://www.journalism.org/wp-content/uploads/sites/8/2016/12/PJ_2016.12.15 fakenews_FINAL.pdf.

BBC News 2021. 'Hundreds dead' because of Covid-19 misinformation. [online] BBC News. Available at: <https://www.bbc.com/news/world-53755067> [Accessed 24 March 2021].

Brennen S., Nielsen K., Howard P., Simon F. 2020. Types sources and claims of COVID19 misinformation. Retrieved 18 August 2020 from

https://reutersinstitute.politics.ox.ac.uk/types-sources-and-claims-covid-19-misinformation 
Bridgman A., Merkley E., Loewen P., Owen T., Ruths D., Teichmann L., Zhilin O. 2020. The causes and consequences of COVID-19 misperceptions: Understanding the role of news and social media. Harvard Kennedy School Misinformation Review

Buonaguro L., Tagliamonte M., Tornesello M., Buonaguro F. 2020. SARS-CoV-2 RNA polymerase as target for antiviral therapy. Journal of Translational Medicine 18(1).

DOI: $10.1186 / \mathrm{s} 12967-020-02355-3$

Carlson S., Dey A., Beard F. 2020. An evaluation of the 2016 influenza vaccination in pregnancy campaign in NSW Australia. Public Health Research \& Practice 30(1).

DOI: $10.17061 /$ phrp29121908

Hu B., Ge X., Wang L., Shi Z. 2015. Bat origin of human coronaviruses. Virology Journal $12(1)$

ITUC-AFRICA 2021. [online] Ituc-africa.org. Available at: <https://www.itucafrica.org/IMG/pdf/ituc-africa_newsletter_special_edition.pdf> [Accessed 24 March 2021].

Kim S. \& Kim Y. 2017. The effect of compliance knowledge and compliance support systems on information security compliance behavior.

Journal of Knowledge Management 21(4) 986-1010. DOI: 10.1108/jkm-08-2016-0353

Krishna Kumar K. \& Geethakumari G. 2014. Identifying Sources of Misinformation in Online Social Networks. Advances In Intelligent Systems And Computing 417-428.

DOI: 10.1007/978-3-319-04960-1_37

Long Q., Tang X., Shi Q., Li Q., Deng H., Yuan J., Hu J., Xu W., Zhang Y., Lv F. et al. 2020. Clinical and immunological assessment of asymptomatic SARS-CoV-2 infections.

Nature Medicine 26(8): 1200-1204.

Lumen 2021. Social Influence | Boundless Psychology. [online] Courses.

lumenlearning.com. Available at:

<https://courses.lumenlearning.com/boundless-psychology/chapter/social-influence/> [Accessed 24 March 2021].

Lumen 2021b. Conformity Compliance and Obedience | Introduction to Psychology. [online] Courses.lumenlearning.com. Available at:

<https://courses.lumenlearning.com/intropsychmaster/chapter/conformity-compliance-andobedience/> [Accessed 24 March 2021].

Mackenzie J. \& Smith D. 2020. COVID-19: a novel zoonotic disease caused by a coronavirus from China: what we know and what we don't.

Microbiology Australia 41(1) 45. DOI: $10.1071 / \mathrm{ma} 20013$ 
Milken Inst. 2020. Milken Institute - Airtable. Retrieved 20 August 2020 from https://airtable.com/shrSAi6t5WFwqo3GM/tblEzPQS5fnc0FHYR/viwDBH7b6FjmIBX5x? blocks=hide.

NAS. 2020. Linking Knowledge with Action for Sustainable Development. Retrieved 21 August 2020 from

http://www.nasonline.org/programs/nas-colloquia/completed_colloquia/linkingknowledge-with-action-for-sustainable-development.html.

Nature 2020. Coronavirus research updates: Vaccines given through the nose could protect against infection. Retrieved 25 August 2020 from https://www.nature.com/articles/d41586020-00502-w

NCDC 2021. Nigeria Centre for Disease Control. [online] Ncdc.gov.ng. Available at: <https://ncdc.gov.ng/diseases/sitreps/?cat=14\&name=An\%20update\%20of\%20COVID19\%20outbreak\%20in\%20Nigeria> [Accessed 17 March 2021].

National Criminal Justice Service 2020. Retrieved 21 August 2020 from https://www.ncjrs.gov/pdffiles1/ojjdp/178926.pdf

Nsoesie E. \& Oladeji O. 2020. Identifying patterns to prevent the spread of misinformation during epidemics. Harvard Kennedy School Misinformation Review. DOI: 10.37016/mr2020-014

Ogbonda P., Douglas K., Moore B. 2020. Knowledge and Compliance with Standard Precautions amongst Healthcare Workers in Selected Hospitals in Rivers State Nigeria. Asian Journal of Medicine and Health 11-22.

DOI: 10.9734/ajmah/2020/v18i230181.

Petrosillo N., Viceconte G., Ergonul O., Ippolito G., Petersen E. 2020. COVID-19 SARS and MERS: are they closely related?

Clinical Microbiology and Infection 26(6): 729-734. DOI: 10.1016/j.cmi.2020.03.026

Sandada M. \& Kambarami P. 2016. The determinants of the compliance to public procurement policy requirements among public enterprises in Zimbabwe. Acta Universitatis Danubius Administratio. 8(1): 43-57

Saunders B. \& Goddard C. 2002. The role of mass media in facilitating community education and child abuse prevention strategies. Child Abuse Prevention Issues Paper: Australian Institute of Family Studies. ISSN 1447-0004 (Online)

Singhal T. 2020. A Review of Coronavirus Disease-2019 (COVID-19).

The Indian Journal Of Pediatrics 87(4): 281-286. DOI: 10.1007/s12098-020-03263-6 
Smith G.D., Ng F., Ho Cheung Li. W. 2020. COVID-19: Emerging compassion courage and resilience in the face of misinformation and adversity.

Journal of Clinical Nursing 29 (9-10): 1425-1428.

Spiteri G., Fielding J., Diercke M., Campese C., Enouf V., Gaymard A., Bella A., Sognamiglio P., Sierra Moros M. et al. 2020. First cases of coronavirus disease 2019 (COVID-19) in the WHO European Region 24 January to 21 February 2020. Eurosurveillance 25(9). DOI: 10.2807/1560-7917.es.2020.25.9.2000178

Wong G., Bi Y., Wang Q., Chen X., Zhang Z., Yao Y. 2020. Zoonotic origins of human coronavirus 2019 (HCoV-19 / SARS-CoV-2): why is this work important?

Zoological Research 41(3) 213-219. DOI: 10.24272/j.issn.2095-8137.2020.031

Worldometer 2020. Nigeria Coronavirus: 54588 Cases and 1048 Deaths - Worldometer. [online] Worldometers.info. Available at:

<https://www.worldometers.info/coronavirus/country/nigeria/>[Accessed 3 Sept. 2020].

Yusuf I., Adam R., Ahmad S., Yee P. 2014. Ebola and compliance with infection prevention measures in Nigeria. The Lancet Infectious Diseases. 14(11): 1045-1046.

DOI: 10.1016/s1473-3099(14)70954-5.

Zheng J. 2020. SARS-CoV-2: an Emerging Coronavirus that Causes a Global Threat. International Journal of Biological Sciences. 16(10): 1678-1685.

DOI: $10.7150 /$ ijbs.45053

To cite this article:

Adeyemi K. 2021. Misinformation about COVID-19 among internet users in Nigeria: Tools to effective public awareness, prevention and control.

International Journal of Modern Anthropology. 2 (15): 469 - 482

DOI: http://dx.doi.org/10.4314/ijma.v2i15.4

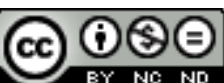

This article, as all articles published in this journal, is under The Creative Commons Attribution: Attribution-NonCommercial-NoDerivatives 4.0 International (CC BY-NC-ND 4.0).

https://creativecommons.org/licenses/by-nc-nd/4.0/ 